\title{
THE ROLE OF SOIL STRUCTURE ON THE PORE FUNCTIONALITY OF AN ULTISOL
}

\author{
J. Dörner ${ }^{1 *}$, P. Sandoval ${ }^{1}$, and D. Dec ${ }^{1}$ \\ ${ }^{1}$ Instituto de Ingeniería Agraria y Suelos, Facultad de Ciencias Agrarias, Universidad Austral de \\ Chile, Casilla 567, Valdivia.*Corresponding author: josedorner@uach.cl
}

\begin{abstract}
A Typic Hapludult was used to evaluate the effect of soil structure and different bulk densities (reached after the destruction of macro aggregates) on functional characteristics of the pore system. The water retention curve, pore-size distribution, shrinkage curve and index were determined in disturbed and structured samples. To evaluate the effect of soil structure on the continuity of the pore system the air permeability at different matrix potentials was measured. From the relationship between the air permeability and air-filled porosity, pore continuity indexes were calculated. The destruction of the soil structure affects the function of its pores. The amount of air-filled pores increased with the reduction of the bulk density, however, the stability and continuity of these pores are low, which affects their functionality. Therefore, the formation of a stable and continuous pore system allows the soil to conduct air, even though they have a restrictive amount of air-filled pores. On the other hand, the soil structure plays a key role in pore stability during drying and, consequently, on the equilibrium between phases. Finally, the highest bulk density $\left(1.1 \mathrm{Mg} \mathrm{m}^{-3}\right)$ does not reach critical values (compaction). However, depending on the bulk density of the soil, it is possible to reach restrictive values of air capacity which affects the air transport in the soil, especially if the porous media is not continuous.
\end{abstract}

Keywords: Soil structure, pores, air permeability, Ultisol.

\section{INTRODUCTION}

Soil is a three phase system which plays different roles in the biosphere, such as: i) regulation of biogeochemical cycles, ii) microorganism habitat and iii) medium for plant roots (Scheffer and Schachshaffel, 2002). Another soil function, particularly of its pores, is to store and conduct fluids like water and air. The latter is relevant not only to crop production (Horn and Fleige, 2009), but also to environmental protection as indicated by Ball et al. (1999) when they refer to the effect of soil compaction on gas emission. The importance of soil functions implies that the characterization of the soil structure, through the quantification of the pores, plays a key role in understanding the soil's ability to store and conduct fluids (Horn et al., 1994; Dörner and Horn, 2006).

Soil structure formation depends on the forming material (Hartge and Horn, 1999). While in coarse textured soils it depends on the presence of the elements that increase the cohesion between particles (e.g. organic matter), the aggregates in the fine textured soils are formed after the swelling and shrinkage processes that conduce to crack formation (Horn and Smucker, 2005). During 
aggregate formation, the rearrangement of soil particles depends on the number and intensity of wetting and drying cycles, the mechanical stability and the presence of organic compounds. The latter is relevant since it allows the three phase system of the soil to reach an equilibrium (Horn et al., 1994) determining the ability of the soil to store and conduct water, air and heat (Horn and Smucker, 2005). However, such soil structure dependent properties may present spatial and temporal variations which has been investigated by many researchers as Boorman and Klaassen (2008) in a Spodosol in Northern Germany, Hu et al. (2009) in an Entisol in China, Dec et al. (2010) and Dörner et al. (2010) in Andisols in southern Chile. These variations occur because soils are subjected to the action of external forces (e.g. tillage and compaction), internal forces (e.g. wetting and drying cycles, soil freezing) and biological activity (e.g. biopore formation by earthworms). The latter implies that soil structure dependent properties are not constant, especially, if the net of pores is destroyed during tillage (Osunbitan et al., 2005) or by animal trampling (Dec et al., 2010) affecting not only the pore volume (increase in bulk density due to soil consolidation after tillage), but also the pore functions (e.g. reduction of hydraulic conductivity) as reported by Osunbitan et al. (2005) and Moret and Arrúe (2007), among others.

Ultisols in southern Chile can present more than $50 \%$ clay in the upper layers and, consequently, bulk densities higher than $1.0 \mathrm{Mg} \mathrm{m}^{-3}$ and restricted permeability. These soils have been used to establish crops (wheat) using conventional methods of tillage which have destroyed and compacted the labile structure of these soils (Ellies and Dörner, 1999) developing an undesirable physical environment for plants (Dörner, 1999). The latter implies temporal variations of structure dependent properties which have not yet been investigated in southern Chile. Therefore, the aim of this investigation was to characterize the soil under in situ conditions and, additionally, to simulate the effect of tillage, destruction of macro aggregates and compaction by means of soil sieving and packing samples at increasing bulk densities. The objective of working with two kinds of soil samples (structured and repacked samples) was to evaluate the effect of soil structure and bulk density on pore functions determined by $i$ ) the water retention curve, ii) the shrinkage capacity and iii) the air permeability.

\section{MATERIALS AND METHODS}

\section{Soil and management}

A Typic Hapludult (Serie Cudico), normally known as Rojo Arcilloso, was used to evaluate the effect of the soil structure and the bulk density (reached after the destruction of macro aggregates) on soil pore functions. According to CIREN (2003), the soil was formed from old-volcanic ashes and presents deep profiles. The topography is complex with slopes ranging from 5 till $20 \%$. The soil textural classes are clay loam to clay between 0-35 cm deep, and clay in deeper horizons (Bt horizon $>35 \mathrm{~cm}$ depth). The soil structure is relatively well developed in the profile presenting fine sub-angular blocky aggregates $(0-35 \mathrm{~cm})$ and a prismatic structure $(>35 \mathrm{~cm})$. The climate is Mediterranean cold with a mean annual temperature of $16.6^{\circ} \mathrm{C}$ and precipitations of $1267 \mathrm{~mm}$ (Novoa and Villaseca, 1989).

The soil was used for prairies dominated by Lollium multiflorum associated with Avena strigosa. Both species were established with pasture regeneration without major soil 
disturbances. These prairies were used as the main source for livestock feeding during the year.

\section{Soil sampling}

Undisturbed and disturbed soil samples were collected (May, 2006) between 2 and $10 \mathrm{~cm}$ of soil depth. The undisturbed soil samples were taken on metallic cylinders of $250 \mathrm{~cm}^{3}$ (height: $5.5 \mathrm{~cm}$ and diameter: $7.0 \mathrm{~cm}$ ). The disturbed material was used to define some general characteristics of the soil and, mainly, to pack soil samples $\left(250 \mathrm{~cm}^{3}\right)$ with different bulk densities. The water retention and shrinkage curves as well as the air permeability were measured for both kinds of samples.

\section{Soil samples packing}

The disturbed soil was dried at $30^{\circ} \mathrm{C}$ for four days and then sieved $(<2 \mathrm{~mm})$. In order to allow a better arrangement of soil particles during packing, the homogenized soil was then moist until a $20 \%$ volumetric water content was reached. Finally, the soil samples were packed at different bulk densities $(0.8$, $0.9,1.0,1.1 \mathrm{Mg} \mathrm{m}^{-3}$ ) following the methodology proposed by Demond et al. (1996). The selected bulk densities are below and above those defined for the undisturbed soil $\left(1.05 \mathrm{Mg} \mathrm{m}^{-3}\right)$. A bulk density of $1.1 \mathrm{Mg} \mathrm{m}^{-3}$ was the highest reached using a Proctor Test. A defined amount of soil was put into the cylinder in layers between 5 and $7 \mathrm{~mm}$ to pack the samples; each layer was homogeneously distributed and, then, according to the defined bulk density, the layers were compacted with different pressures for three minutes. The following treatments were defined: disturbed soil $\left(\mathrm{dBd}_{(0.8)}\right.$, $\left.\mathrm{dBd}_{(0.9)}, \mathrm{dBd}_{(1.0)}, \mathrm{dBd}_{(1.1)}\right)$ and structured soil $\left(\mathrm{eBd}_{(1.05)}\right)$.

\section{Laboratory analysis}

In order to have a general characterization of the soil the $\mathrm{pH}\left(\mathrm{H}_{2} \mathrm{O}\right)$ and the amount of organic matter was determined (Sadzawka et al., 2006). The particle density was measured with the liquid pycnometer method using de-aired water as the displacing liquid (Blake and Hartge, 1986). For all this analysis 3 repetitions were used.

The water retention and shrinkage curves were determined simultaneously. The samples were first carefully saturated from beneath during a two day period to avoid air inclusions in pores, and then, drained at water potential values of $-1,-2$, $-3,-6,-15,-33$, and $-50 \mathrm{kPa}$. To define the volume of fine pores samples in cylinders of $20 \mathrm{~cm}^{3}$ were equilibrated at a water potential of $-1500 \mathrm{kPa}$. The water content was registered at each water potential with an electronic balance. To characterize the shrinkage behaviour at water potentials lower than $-50 \mathrm{kPa}$, samples were shifted to air dry conditions $\left(20 \pm 2{ }^{\circ} \mathrm{C}\right)$ for 14 days and then stepwise oven dried at 30,60 , and $105^{\circ} \mathrm{C}$. From saturation and throughout the different water tensions and dehydration temperatures, the water content and vertical deformation (measured in 7 points for each soil sample) were recorded with an electronic balance (Precisa, $0.01 \mathrm{~g}$ accuracy) and caliper gauge (Holex, 0.05 $\mathrm{mm}$ accuracy), respectively. The vertical deformation of the soil was used to correct the water retention curve (Dörner et al., 2010). To calculate the void ratio and total porosity a particle density value of $2.42 \mathrm{Mg} \mathrm{m}^{-3}$ was used.

The shrinkage curve was characterized in relation to the void ratio $(e)$ and moisture ratio $(\vartheta)$ as previously done by Peng and Horn (2005), Cornelis et al. (2006) and Dörner et al. (2009 a, b). To register the unidimensional deformation 
of the soil from saturated to dry conditions, the coefficient of linear extensibility (COLE), described by Grossman et al. (1968), was calculated:

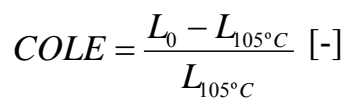

where,

$$
\begin{aligned}
L_{0}= & \begin{array}{l}
\text { Length of the sample at } \\
\text { saturation }(0 \mathrm{hPa})
\end{array} \\
L_{105^{\circ} \mathrm{C}}= & \begin{array}{l}
\text { Length of the sample alter } \\
\text { oven drying at } 105^{\circ} \mathrm{C}
\end{array}
\end{aligned}
$$

The air permeability $\left(k_{a}\right)$ was measured in an air permeameter (Leiva, 2009; Sandoval, 2009) when the soil samples reached matrix potentials of $-6,-15,-33$ and $-50 \mathrm{kPa}$. The air permeability $k_{a}$ $\left[\mu \mathrm{m}^{2}\right]$ was calculated from the air conductivity $k_{l}\left[\mathrm{~cm} \mathrm{~s}^{-1}\right]$ as follows:

$$
\mathrm{k}_{\mathrm{a}}=\mathrm{k}_{l} \cdot \frac{\eta}{\rho_{l} \cdot g}\left[\mu \mathrm{m}^{2}\right]
$$

where $\eta$ is the air viscosity $\left[\mathrm{g} \mathrm{s}^{-1} \mathrm{~cm}^{-1}\right], \rho_{l}$ is the air density $\left[\mathrm{kg} \mathrm{m}^{-3}\right]$ and $g$ is the gravitational acceleration $\left[\mathrm{m} \mathrm{s}^{-2}\right]$.

In order to evaluate functional characteristics of the pore system, the pore continuity index $K_{1}$ was calculated (Groenevelt et al., 1984):

$$
K_{1}=\frac{k_{a}}{\varepsilon_{a}}\left[\mu \mathrm{m}^{2} / \mathrm{cm}^{3} \mathrm{~cm}^{-3}\right]
$$

which relates the air permeability $\left(k_{a}\right)$ to the air filled porosity $\left(\varepsilon_{a}\right)$. The latter was calculated from the water retention curve, as the difference between total porosity and the volumetric water content at a given matric potential. Large values of $K_{1}$ indicate that the pore system had a high capacity to transmit fluids due to a great continuity and interconnection between pores (Schjønning et al., 1999). Ball et al.
(1988) also suggested that $k_{a}$ and $\varepsilon_{a}$ may be related as follows:

$\log \left(k_{a}\right)=\log (\mathrm{M})+\mathrm{N} \log \left(\varepsilon_{a}\right)$

where $\mathrm{M}$ and $\mathrm{N}$ are empirical parameters. $\mathrm{N}$ is a pore continuity index, which reflects the increase of $k_{a}$ with increasing $\varepsilon_{a}$ or the decrease of pore tortuosity and surface area with the increasing fraction of pores available for flow (Ahuja et al., 1984; Ball et al., 1988). The latter also proposed that an estimate of blocked airfilled pore space (equation 5) may be derived from equation 4 . Soils with an air permeability as little as $1 \mu^{2}$ may be considered as impermeable; therefore, the intercept of the abscissa may be regarded as an estimate of blocked air-filled pore space (blocked porosity $\varepsilon_{b}$ ), which does not take part in the transport of air by convection (Ball et al., 1988).

$\varepsilon_{b}=10^{(-\log \mathrm{M}) / \mathrm{N}}$

\section{Statistical analysis}

Averages and standard errors were calculated for each treatment. In order to determine the effect of soil structure and bulk density on physical properties of the soil, an analysis of variance was applied $(p \leq 0.05)$. The differences of means were assessed by the Tukey-test $(p \leq 0.05)$.

\section{RESULTS}

The amount of organic matter, soil texture, bulk density and pore-size distribution (Table 1) registered from the site presented typical values for the soil Serie according to IREN-UACh (1978) and Ellies and Dörner (1999). 
Table 1. General characteristics of studied soil (Typic Hapludult).

\begin{tabular}{cccccccccc}
\hline TC & OM & pH & Bd & Pd & TP & wCP & nCP & MP & FP \\
& {$[\%]$} & {$[-]$} & $-------\left[\mathrm{mg} \mathrm{m}^{-3}\right]----$ & $----------------[\%]$ & $-------------~$ \\
\hline Clay & $6.5 \pm 0.1$ & $5.6 \pm 0.1$ & $1.05 \pm 0.01$ & $2.42 \pm 0.1$ & $57 \pm 0.2$ & $3 \pm 0.5$ & $5 \pm 0.8$ & $20 \pm 1.3$ & $33 \pm 0.5$ \\
loam & & & & & & & & & \\
\hline
\end{tabular}

TC: Textural class; OM: organic matter; Bd: bulk density; Pd: particle density; TP: total porosity; $\mathrm{wCP}$ wide coarse pores $(>50 \mu \mathrm{m}) ; \mathrm{nCP}$ : narrow coarse pores $(50-10 \mu \mathrm{m})$; MP: middle pores $(<10-0,2 \mu \mathrm{m})$; FP: fine pores $(<0,2 \mu \mathrm{m})$.

Effect of bulk density and soil structure on porosity and their stability

The soil reached a volumetric water content at $\mathrm{pF} 0$ (water saturation, similar to total porosity, TP) which ranged between $58 \%$ and $72 \%$ (Figure 1). The disturbed soil, with the exception of $\mathrm{dBd}_{(1.1)}$, reached a water content at $\mathrm{pF} 0$ higher than the structured samples. In general, the shapes of the curves differ between treatments particularly in the $\mathrm{pF}$ range between 0 and 2.52 .

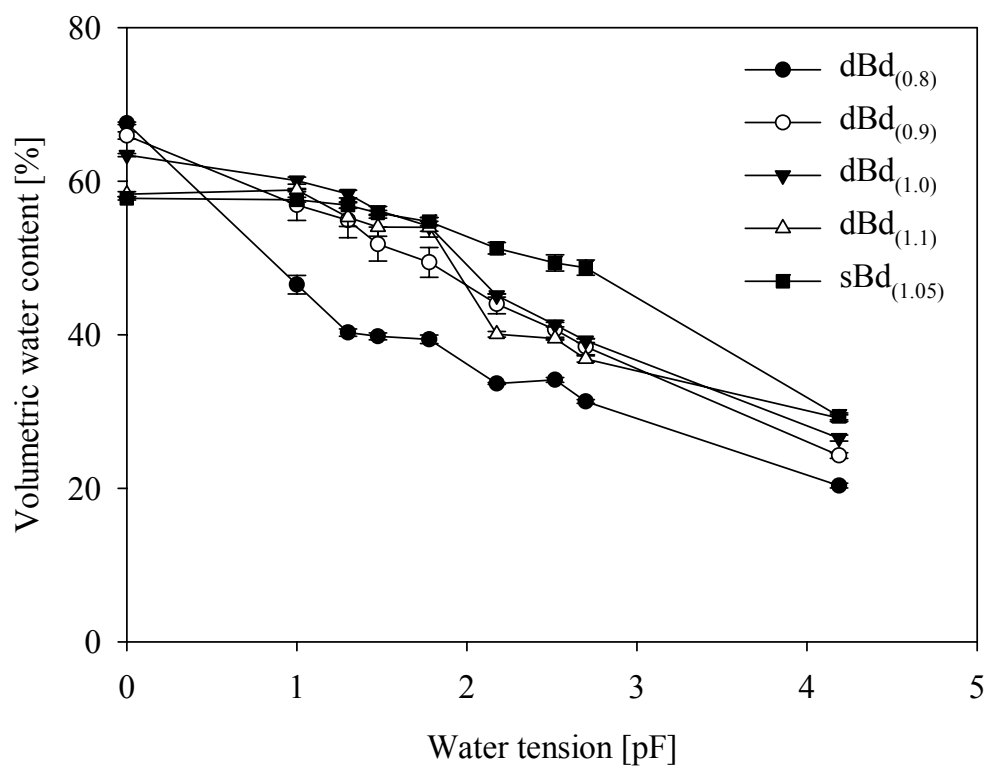

Figure 1. Water retention curves for the disturbed $(\mathrm{dBd}(0.8-1.1))$ and undisturbed soil $(\operatorname{sBd}(1.05))$. Bars indicate \pm 1 standard error $(n=7)$. 
Figure 2 presents the effect of the bulk density and structure on the pore-size distribution. While the volume of wide coarse pores (wCP; $\phi>50 \mu \mathrm{m}$ also defined as air capacity) decreases, the narrow coarse pores (nCP; $\phi 50-10 \mu \mathrm{m})$ and fine pores (FP; $\phi<0.2 \mu \mathrm{m})$ tend to increase. Treatment $\mathrm{dBd}_{(0.8)}$ presented the highest volume of wCP (48\%), but had the lowest amount of other pores as compared to the other treatments. The structured soil $\left(\mathrm{eBd}_{(1.05)}\right)$ presented the lowest air capacity, but the highest amount of middle pores (MP; $\phi<10$ $0.2 \mu \mathrm{m} ; 32.3 \%$ ) and fine pores $(49.7 \%)$.

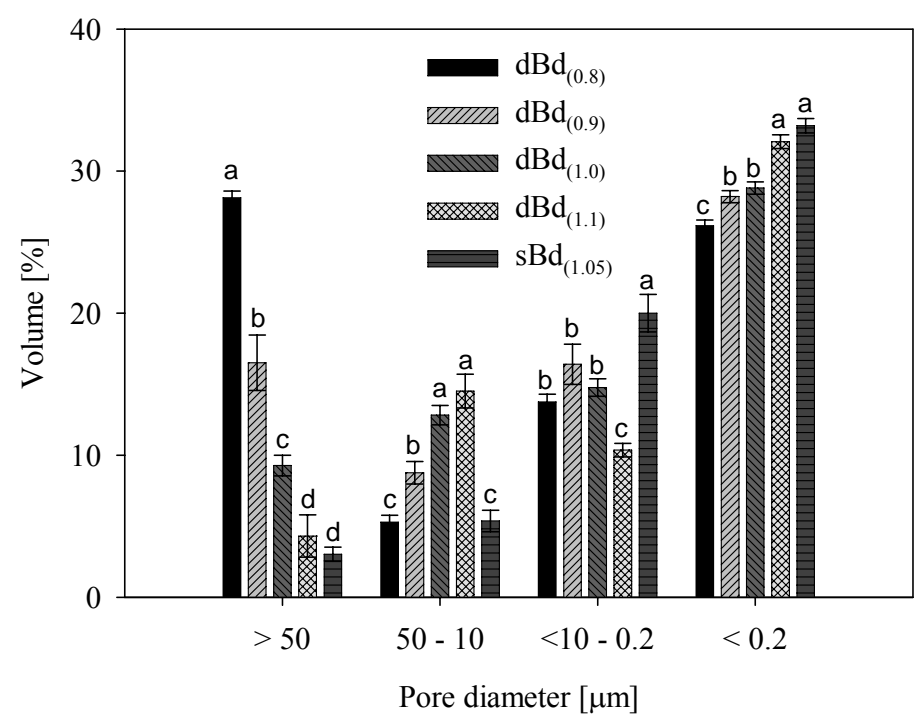

Figure 2: Pore-size distribution for the disturbed $\left(\mathrm{dBd}_{(0.8-1.1)}\right)$ and structured soil $\left(\mathrm{sBd}_{(1.05)}\right)$. wCP (wide coarse pores, $\varnothing>50 \mu \mathrm{m}$ ); nCP (narrow coarse pores, $\varnothing 50-10$ $\mu \mathrm{m}$ ); MP (middle pores, $\varnothing<10-0.2 \mu \mathrm{m}$ ); FP (fine pores, $\varnothing<0.2 \mu \mathrm{m}$ ). Different letters indicate significant differences between treatments for the same pore type. Bars indicate \pm 1 standard error $(n=7)$.

All soil samples shrunk as a consequence of soil drying (Figure 3). The samples with lower bulk densities presented a larger deformation at higher moisture ratios. Additionally, it was assessed that eBd $d_{(1.05)}$ and $\mathrm{dBd}_{(1.1)}$ presented almost the same shrinkage curve. The coefficient of linear extensibility (COLE) decreased as the bulk density increased (Figure $4 ; p \leq 0.10$ ). However, it has to be remarked that notwithstanding its higher bulk density, $\mathrm{dBd}_{(1.1)}$ presented a larger COLE than $\mathrm{eBd}_{(1.05)}$.

\section{Effect of bulk density and structure on pore functions}

The air permeability $\left(k_{a}\right)$ decreased exponentially as the bulk density of the disturbed soil increased (Figure 5). However, it was observed that $\mathrm{eBd}_{(1.05)}$ presented a higher $k_{a}$ as compared to the disturbed soil samples with similar bulk densities $\left(\mathrm{dBd}_{(1.0)} \mathrm{y} \mathrm{dBd}_{(1.1)}\right)$ and the same volume of coarse pores $\left(\mathrm{dBd}_{(1.1)}\right)$.

The air permeability increased with a greater amount of air-filled pores 
available to air transport by convection (Figure 6). The latter, however, was not observed by $\mathrm{dBd}_{(0.8)}$ since no significant relationship was found $(p>0.1)$. The structured and disturbed soil presented remarkable differences: while the first group of samples is located above the 1:1 lines, the second are below this line. The parameters $\mathrm{M}, \mathrm{N}$ and the blocked porosity (Table 2) tend to decrease with the increment of bulk density from $\mathrm{dBd}_{(0.9)}$ to $\mathrm{dBd}_{(1.1)}$. The structured soil presented the lowest values of $\mathrm{N}$ and $\varepsilon_{b}$. Finally, Figure 7 shows that the disturbed soil had less pore continuity than the structured soil ( $p$ $\leq 0.05)$.

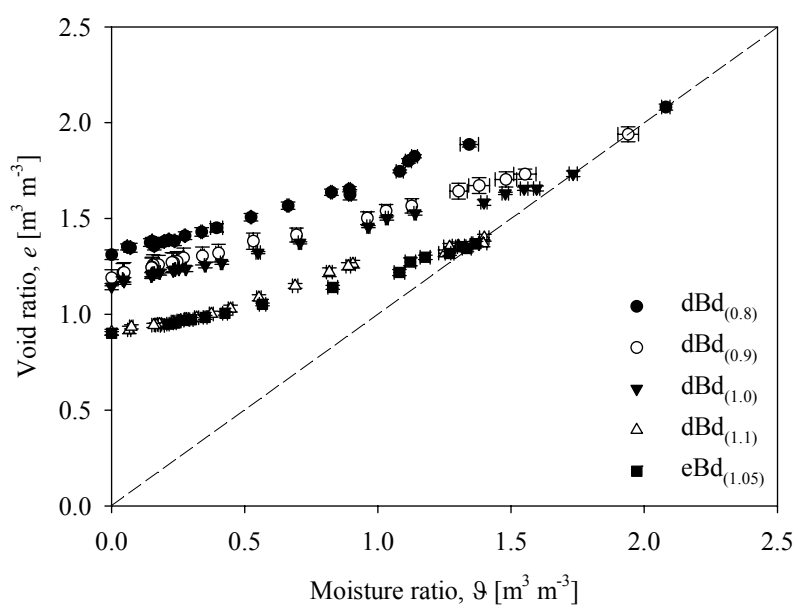

Figure 3. Shrinkage curves for the disturbed $\left(\mathrm{dBd}_{(0.8-1.1)}\right)$ and undisturbed soil $\left(\operatorname{sBd}_{(1.05)}\right)$. Bars indicate \pm 1 standard error $(n=7)$.

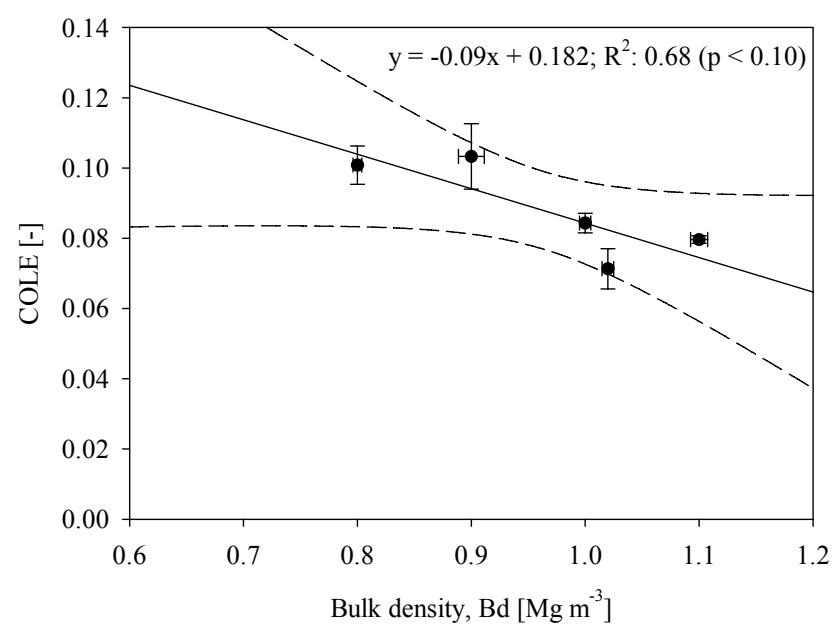

Figure 4. Coefficient of linear extensibility (COLE) as a function of soil bulk density. Bars indicate \pm 1 standard error $(n=7)$. 


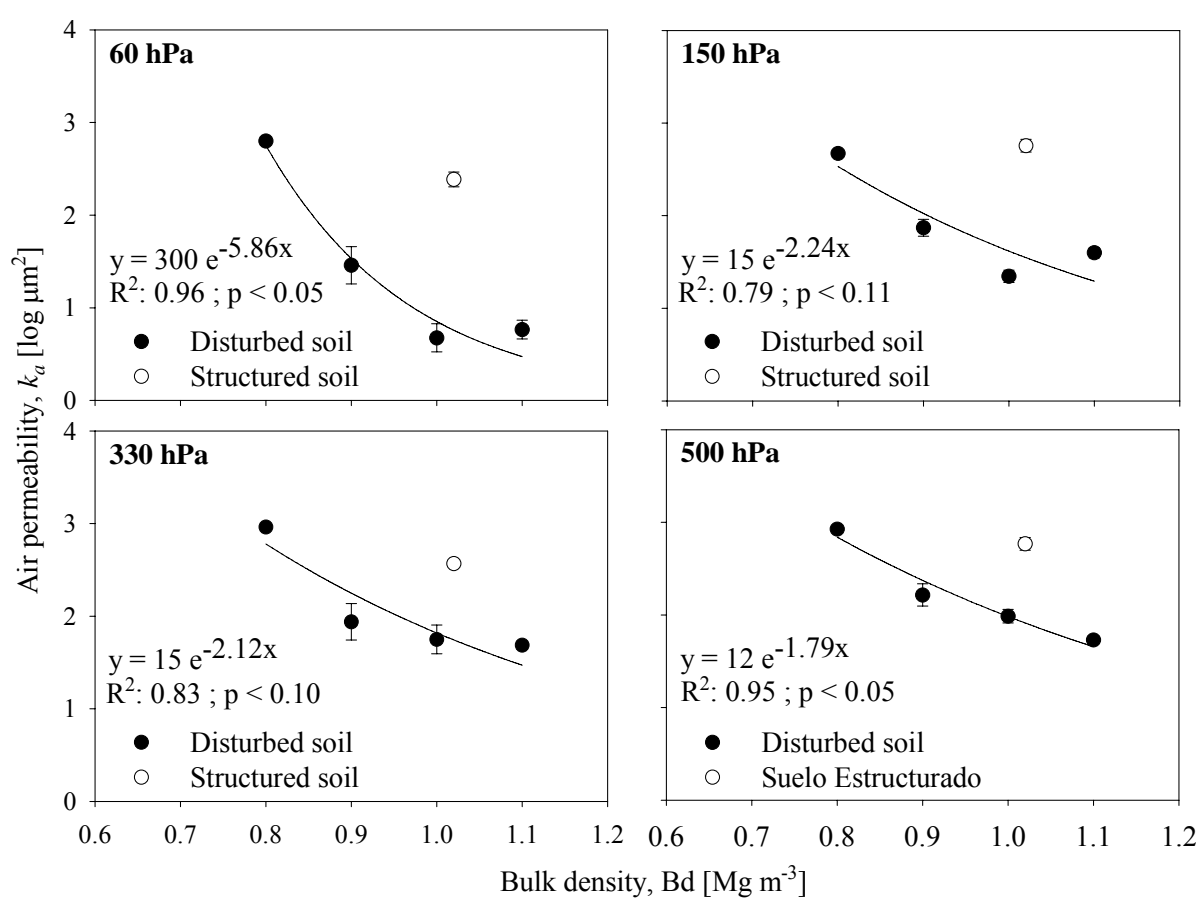

Figure 5. Air permeability $\left(k_{a}\right)$ as a function of the bulk density of the disturbed soil for different water tensions. The white points correspond to the structured soil. Bars indicate \pm 1 standard error $(\mathrm{n}=7)$.

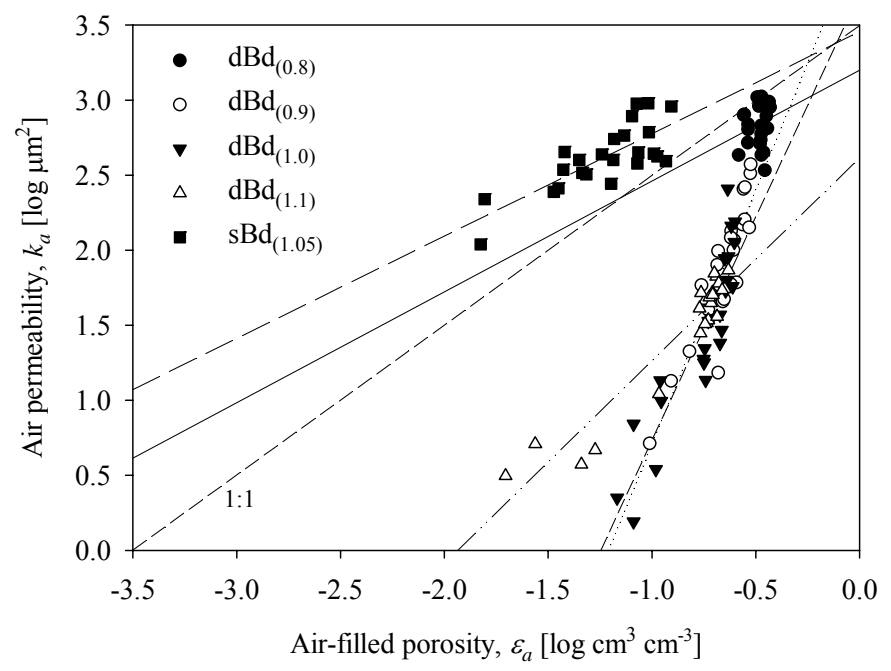

Figure 6. Air permeability $\left(k_{a}\right)$ as a function of the air-filled porosity $\left(\varepsilon_{a}\right)$ for the disturbed $\left(\mathrm{dBd}_{(0.8-1.1)}\right)$ and undisturbed soil $\left(\mathrm{sBd}_{(1.05)}\right)$. 
Table 2. Regression parameters and blocked porosities derived from equations 4 [log $\left.\left(k_{a}\right)=\log (\mathrm{M})+\mathrm{N} \log \left(\varepsilon_{a}\right)\right]$ and $5\left[\varepsilon_{b}=10^{(-\log \mathrm{M}) / \mathrm{N}}\right]$.

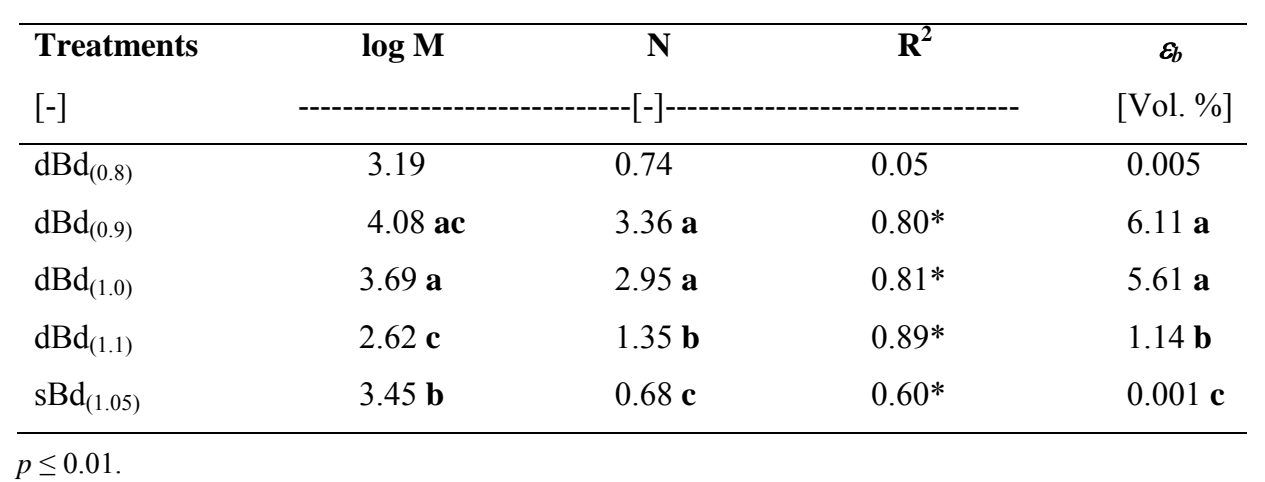

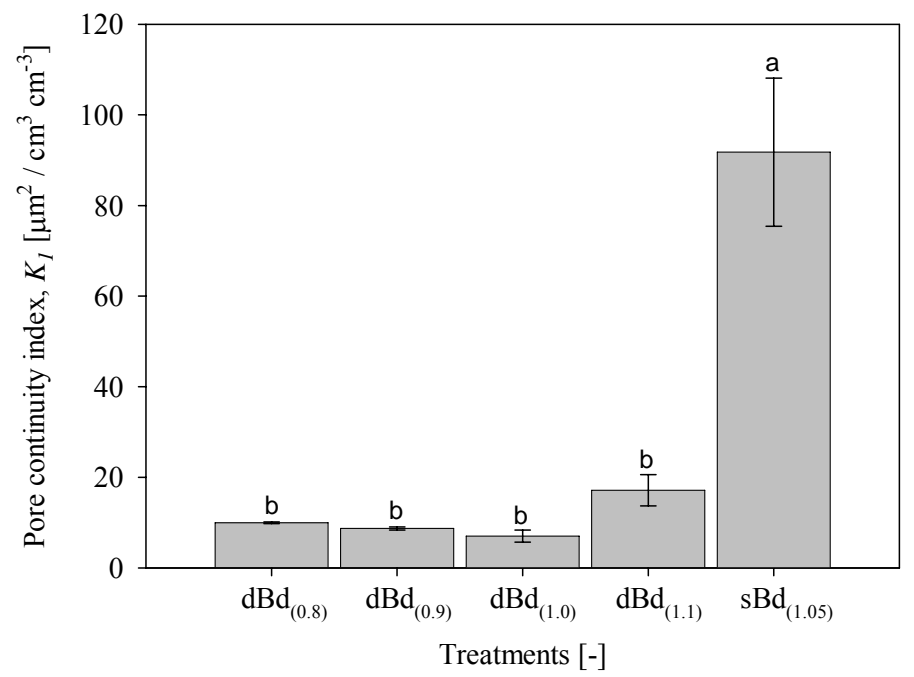

Figure 7. Pore continuity index $K_{1}$ for the different treatments. Different letters indicate significant differences between treatments. Bars indicate \pm 1 standard error $(n=7)$.

\section{DISCUSSION}

The role of soil structure on pore volume and their stability

Tillage activities induced a destruction of the soil structure which may have resulted, depending on the type of tillage, in a complete homogenization of the soil. The bulk density reached after tillage depends on the soil texture, the amount of organic matter, the water content and the pressure on the soil (Horn et al., 1994). Considering that the studied soil is the 
same, the observed differences between the homogenized and structured material can be ascribed to: i) aggregate destruction during sieving (like after tillage) and subsequent compaction $\left(\mathrm{dBd}_{(0.8-1.1)}\right)$ y ii) structure formation due to biological activity (e.g. roots and earthworms) and to the occurrence of wetting and drying cycles $\left(\mathrm{eBd}_{(1.05)}\right)$, as discussed by Horn and Smucker (2005). In these terms, Moret and Arrúe (2004) studied the hydraulic properties of a Xerollic Calciorthid before and after tillage and concluded that these properties change temporarily due to tillage activities (bulk density decreases and hydraulic conductivity increases) and natural consolidation of the soil (bulk density increases and hydraulic conductivity decreases). On the other hand, Leiva (2009) analysed the pore-size distribution of a homogenized and structured Ultisol (the same soil as the present study) subjected to wetting and drying cycles. He concluded that these cycles induced an increment in MP (water available for plants) instead of macro pores (available for gas transport), mainly in the disturbed soil.

The changes in bulk density affected the soil structure and its dependent properties. The water retention curve (Figure 1), as a consequence of the increasing bulk density, showed changes in the slope mainly in the range of macro pores ( $\mathrm{pF} 0-\mathrm{pF} 2.5$ ) tending to converge in the micro pore range since those pores are texture dependent. The soil homogenization increased the air capacity, which in the case of the studied soil is relevant since it normally presents a deficient amount of macro pores; however, at the same time creates an unstable pore system susceptible to be deformed after drying (Figure 4; COLE > 0.06 is considered a great shrinkage capacity according to Peng et al., 2007), which probably increased the temporal variations of the soil structure. On the other hand, the soil texture did not change with soil compaction, therefore, the amount of micro pores should remain constant (Kutilek et al., 2006). However, some differences were observed (Figure 2) which has also been assessed by Garnier et al. (2004), Hayashi et al. (2006) and Dec et al. (2008). They mentioned that structured soils may present a higher amount of micro pores than disturbed (or non-structured) soils as a consequence of aggregation. Therefore, we have a dynamic pore system presenting changes mainly in the macro pore range, which has a major impact in pore functions as discussed by many authors (Fazekas, 2005; Hayashi et al., 2006; Horn and Smucker, 2005; Horn and Fleige, 2009).

\section{Soil structure and pore functions}

The effect of soil tillage, compaction and resilience should not be evaluated only through the changes in the pore-size distribution and their stability (Figure 2 and 4), but also according to the ability of the soil pores to conduct water and air (Figure 6 and 7). The latter is enhanced by the fact that the structured soil, in spite of its lower air-filled porosity (only comparable to $\mathrm{dBd}_{(1.1)}$ ), presented the second highest air permeability (Figure 5 and 6) and the maximum pore continuity index $K_{1}$ (Figure 8).

Horn and Fleige (2009) presented critical values of different soil physical properties to verify a damaging subsoil compaction concerning crop production. The highest bulk density reached in the present study $\left(1.1 \mathrm{Mg} \mathrm{m}^{-3}\right)$ did not overcome the critical value $(>1.7 \mathrm{Mg}$ $\mathrm{m}^{-3}$ ) proposed by the mentioned authors, however, the air capacity of that treatment exceeded the limit $(<8 \%)$ showing the impact of soil compaction after tillage. On the other hand, the structured soil reached 
restrictive values of air capacity $(<8 \%)$, however, the air conductivity of these pores $\left(0.009 \mathrm{~cm} \mathrm{~s}^{-1}\right)$ is greater than the critical value $\left(0.0012 \mathrm{~cm} \mathrm{~s}^{-1}\right)$ presented by Horn and Fleige (2009). The latter highlights the relevance of the interconnection and continuity of the pore system reached after the soil structure formation (Horn and Smucker, 2005), which allows the soil to conduct air in spite of the high level of water saturation (low volume of blocked pores, Table 2). In this sense, large values of $K_{1}$ indicate a high level of soil pore organization, which allows the soil to conduct air although the air-filled pores available to transport by convection are low. A high pore organization is relevant to conduct water to plant roots (Horn and Smucker, 2005) but at the same time may induce preferential flow in soils (Dörner and Horn 2006; Fazekas, 2005).

The relevance of a continuous pore system has been mentioned by many authors (Horn and Smucker, 2005; Dörner and Horn, 2006) considering those that have studied the temporal variation of soil porosity and continuity as a consequence of soil management (Osunbitan et al., 2005), land use (Hu et al., 2009) and grazing (Dec et al., 2010). Osunbitan et al. (2005) in an Oxic Tropudalf (sandy loam) assessed that the bulk density increases and hydraulic conductivity decreases few weeks after tillage (they considered four treatments from NoTillage till conventional tillage). However, they highlighted that the soil that maintains its structure (No-Tillage) presented a higher hydraulic conductivity as compared to ploughed soils. Finally, they concluded that tillage systems with a high degree of manipulation of the soil break (interrupt) the pore interconnections affecting the water movement in the soil. On the other hand, $\mathrm{Hu}$ et al. (2009) mentioned that the benefits of tillage (e.g. reduction of bulk density) has a limited effect in time since soil structure dependent properties present temporal variations due to soil management (Logsdon and Jaynes, 1996), biological activity (Petersen et al., 2008), rainfall (Somaratne and Smettem, 1993), soil consolidation (Moret and Arrúe, 2007), wetting and drying cycles (Bormann and Klaassen, 2008) and soil erosion (Genereux et al., 2008). The latter underlines the importance of a stable and functional pore system according to the crop requirements, i.e. enough contact points to improve the mechanical stability of the soil which should not affect the root development, but allow, at the same time, a sufficient volume of interconnected pores to assure the gas exchange, water movement and heat transport.

\section{CONCLUSIONS}

The destruction of soil structure affects the pore functions. As a consequence of a reduction of the bulk density, the air capacity was improved; however, the pore stability was affected as well as its continuity. The formation of a stable and continuous pore system allowed the soil to conduct enough air, although a critical volume of air capacity was reached. Therefore, along with evaluating the soil's capacity to retain fluids, we conclude that it is of great importance to know the soil's ability to conduct water and air.

The studied soil presents a great shrinkage capacity (COLE $>0.06)$ which decreases as the bulk density increases. The structured soil presents a lower COLE indicating that the soil structure formation plays an important role in pore stability allowing a particle arrangement that assures the equilibrium between phases.

The air permeability decreased exponentially with the increment of the 
bulk density of the undisturbed soil samples. The structure development induced the formation of a continuous pore system which allows the soil to conduct a large amount of air, even at similar bulk densities when disturbed and undisturbed soil sample were compared. Finally, the highest bulk density reached in laboratory conditions did not exceed a critical value of subsoil compaction concerning crop production. However, depending on the bulk density of the soil, it is possible to reach critical values of air capacity, especially if the pore system is not continuous (e.g. as a consequence of compaction after tillage).

\section{ACKNOWLEDGEMENTS}

This study was sponsored by FONDECYT 11060130. Dorota Dec thanks the FONDECYT Postdoctoral Program 3090038. We appreciate the revision of English usage by Christine Harrower.

\section{REFERENCES}

\begin{abstract}
Ahuja, L.R., Naney, J.W., Green, R.E., Nielsen, D.R. 1984. Macroporosity to characterize spatial variability of hydraulic conductivity and effects of land management. Soil Sci. Soc. Am. J. 48, 699-702.
\end{abstract}

Ball, B.C., O‘Sullivan, M.F., Hunter, R. 1988 Gas diffusion, fluid flow and derived pore continuity indices in relation to vehicle traffic and tillage. J. Soil Sci. 39, 327-339.

Ball B.C., Scott A., Parker J.P. 1999. Field $\mathrm{N}_{2} \mathrm{O}, \mathrm{CO}_{2}$ and $\mathrm{CH}_{4}$ fluxes in relation to tillage, compaction and soil quality in Scotland. Soil Till. Res. 53, 29-39.

Blake, G. R. and Hartge K. H. 1986. Particle density. p. 377-382. In: Methods of soil analysis. Part I. Physical and mineralogical methods. A.
Klute (ed). 2d ed. Agronomy Monography no. 9. ASA., SSSA. Madison WI, USA.

Bormann, H., Klaassen, K. 2008. Seasonal and land use dependent variability of soil hydraulic and soil hydrological properties of two German soils. Geoderma 145, 295-302. CIREN 2003. Estudio agrológico X Región. Tomo 1. 199 p.

Cornelis, W.M., Corluy, J., Medina, H., Díaz, J., Hartmann, R., Van Meirvenne, M., Ruiz, M. 2006. Measuring and modelling the soil shrinkage characteristic curve. Geoderma 137 , 179-191.

Dec, D., Dörner, J., Becker-Fazekas, O., Horn, R. 2008. Effect of bulk density on hydraulic properties of homogenized and structured soils. R.C. Suelo Nutr. Veg. 8 (1), 1-13.

Dec, D., Dörner, J., Balocchi, O. 2010. Spatial and temporal changes of soil physical properties of an Andisol in southern Chile as a consequence of grazing and wetting and drying cycles. 19th World Congress of Soil Science, Soil Solutions for a Changing World. Available online: http://www.iuss.org/19th\%20WCSS/symposium/ 2.1.2.html.

Demond, A. H., Oliviera, I. B., Salehzadeh, A. 1996. Packing of sands for the production of homogeneous porous media. Soil Sci. Soc. Am. J. $60,49-53$.

Dörner, J. 1999. Transmisión de tensiones en un suelo Palehumult bajo distintas condiciones de humedad. Tesis Lic. Agr. Valdivia. Universidad Austral de Chile, Facultad de Ciencias Agrarias. $85 \mathrm{p}$.

Dörner, J., Horn, R. 2006. Anisotropy of pore functions in structured Stagnic Luvisols in the weichselian moraine region in $\mathrm{N}$ Germany. J. Plant Nutr. Soil Sci. 169, 213-220.

Dörner, J., Dec, D., Peng, X., Horn, R. 2009a. Efecto del cambio de uso en la estabilidad de la estructura y la función de los poros de un Andisol (Typic Hapludand) del sur de Chile. R.C. Suelo Nutr. Veg. 9(3), 190-209.

Dörner, J., Dec, D. Peng, X., Horn, R. 2009b. Change of shrinkage behavior of an Andisol in southern Chile: Effects of land use and wetting/drying cycles. Soil Till. Res. 106, 45-53.

Dörner, J., Dec, D. Peng, X., Horn, R. 2010. Effect of land use change on the dynamic behaviour of structural properties of an Andisol 
in southern Chile under saturated and unsaturated hydraulic conditions. Geoderma 159, 189-197.

Ellies, A., Dörner, J. 1999. Distribucion de tensiones en un suelo Palehumult ejercida con el tráfico de la maquinaria agrícola. Agro Sur 27(2), $1-9$

Fazekas, O. 2005. Bedeutung von Bodenstruktur und Wasserspannung als stabilisierenre Kenngrößen gegen intesive mechanische Belastungen in einer Parabraunerde aus Löss unter Pflug- und Mulchsaat. Ph. D. Thesis. Schriftenreihe des Instituts für Pflanzenernährung und Bodenkunde, Christian Albrechts University, Kiel, Germany, Nr. 67, 182 p. ISBN: 0933-680 $\mathrm{X}$.

Genereux, D.P., Leahy, S., Mitasowa, H., Kennedy, C.D., Corbett, D.R. 2008. Spatial and temporal variability of streambed hydraulic conductivity in West Bear Creek, North Carolina, USA. J. Hydrol. 358 (3-4), 332-353.

Garnier, P., Ezzine, N., De Gryze, S., Richard, G. 2004. Hydraulic properties of soil-straw mixtures. Vadose Zone J. 3, 714-721.

Groenevelt, P. H., Kay, B. D., Grant, C. D 1984. Physical assessment of a soil with respect to rooting potential. Geoderma $34,101-114$.

Grossman, R. H., Brasher, B. R., Franzmeier, D. P., Walker, J. L. 1968. Linear extensibility as calculated from natural-clod bulk density measurements. Soil Sci. Soc. Am. Proc. 32, 570573.

Hartge, K. H., Horn, R. 1999. Einführung in die Bodenphysik. Enke, Stuttgart, 304 p.

Hayashi, Y., Ken'ichirou, K., Mizuyama, T. 2006. Changes in pore size distribution and hydraulic properties of forest soil resulting from structural development. Journal of Hydrology $331,85-102$.

Horn, R., Taubner, H., Wuttke, M. Baumgartl, T. 1994. Soil physical properties related to soil structure. Soil Till. Res. 35, 23-36.

Horn, R., Smucker, A. 2005. Structure formation and its consequences for gas and water transport in unsaturated arable and forest soils. Soil Till. Res. 82, 5-14.

Horn, R., Fleige, H. 2009. Risk assessment of subsoil compaction for arable soils in Northwest Germany at farm scale. Soil Till. Res. 102, 201208.
Hu, W., Shao, M., Wang, Q., Fan, J., Horton, R. 2009. Temporal changes of soil hydraulic properties under different land uses. Geoderma 149, 355-366.

Instituto De Recursos Naturales (IREN) Universidad Austral De Chile (UACh), 1978. Estudio de los suelos de la Provincia de Valdivia. Santiago, Chile. 178 p.

Kutílek, M., L. Jenele, Panayiotopoulos, K.P. 2006. The influence of uniaxial compression upon pore size distribution in bi-model soils. Soil Till. Res. 86:27-37.

Leiva, C. 2009. Caracterización del monto, funcionalidad y evolución del sistema poroso de un Palehumult al ser sometido a ciclos de formación de estructura. Tesis Lic. Agr. Valdivia. Universidad Austral de Chile, Facultad de Ciencias Agrarias. 78 p.

Logsdon, S. D., Jaynes, D. B. 1986. Spatial variability of hydraulic conductivity in a cultivated field at different times. Soil Sci. Soc. Am. J. 60, 703-709.

Moret, D., Arrúe, J. L. 2007. Dynamics of soil hydraulic properties during fallow as affected by tillage. Soil Till. Res. 96, 103-113.

Novoa, R., Villaseca, S. 1989. Mapa agroclimático de Chile. Instituto de Investigaciones Agropecuarias (INIA), Santiago. $221 \mathrm{p}$.

Osunbitan, J. A., Oyedele, D. J., Adekalu, K.O. 2005. Tillage effects on bulk density, hydraulic conductivity and strength of a loamy sands oil in Southwestern Nigeria. Soil Till. Res. $82,57-64$.

Peng, X., Horn, R. 2005. Modelling soil shrinkage curve across a wide range of soil types. Soil Sci. Soc. Am. J. 69, 584-592.

Peng, X., Horn, R., Smucker, A. 2007. Pore shrinkage dependency of inorganic and organic soils on wetting and drying cycles. Soil Sci. Soc. Am. J. 71, 1095-1104.

Petersen , C. T., Trautner, A., Hansen, S. 2008. Spatio-temporal variation of anisotropy of saturated hydraulic conductivity in a tillage sandy loam soil. Soil Till. Res. 100 (1-2), 108-113.

Sadzawka, A., Carrasco, M.A., Grez, R. Mora, M.L., Flores, H., Neaman, A. 2006. Métodos de análisis recomendados para los 
suelos chilenos. Serie Actas $\mathrm{N}^{\circ}$ 34. Instituto de Investigaciones Agropecuaria. Chile, 164 pp.

Sandoval, P. 2009. Curva de retención de humedad, de contracción y de permeabilidad de aire en función de distintas densidades aparentes de un suelo rojo arcilloso. Tesis Lic. Agr. Valdivia. Universidad Austral de Chile, Facultad de Ciencias Agrarias. 67 p.

Scheffer, F., Schachtschabel, P. 2002. Lehrbuch der Bodenkunde. Blume, H-P., G.W. Brümmer, U. Schwertmann, R. Horn, I. Kögel-Knaber, K Stahr, K. Auerswald, L. Beyer, A. Hartmann, N. Litz, A. Scheinost, H. Stanjek, G. Welp und B.M Wilke. 15. Aufl., Spektrum Akademischer Verlag, Berlin, $593 \mathrm{p}$.
Schjønning, P., Thomsen, I.K., Møberg, J.P., de Jonge, H., Kristensen, K., Christensen, B. 1999. Turnover of organic matter in differently textured soils. I. Physical characteristics of structurally disturbed and intact soils. Geoderma $89,177-198$.

Somaratne, N.M., Smattem, K.R. 1993. Effect of cultivation and raindrop impact on the surface hydraulic properties of an Alfsol under wheat. Soil \& Tillage Research 26, 115-125. 